\title{
Propidium monoazide-polymerase chain reaction for detection of residual periprosthetic joint infection in two-stage revision
}

\author{
Mohamed Askar $^{1} \cdot$ Mariam Sajid $^{1} \cdot$ Yassar Nassif $^{2} \cdot$ Waheed Ashraf $^{1} \cdot$ Brigitte Scammell $^{1,2} \cdot$ Roger Bayston $^{1}$ (i)
}

Received: 19 June 2019 / Accepted: 22 September 2019 / Published online: 5 October 2019

(c) The Author(s) 2019

\begin{abstract}
False negative culture results in periprosthetic joint infection (PJI) are not uncommon particularly when patients have received long term antibiotics. Polymerase chain reaction (PCR) has a lower specificity partly due to detection of residual DNA from dead bacteria. Propidium monoazide (PMA) prevents DNA from dead bacteria from being amplified during the PCR. This study aimed to determine the role of PMA in PCR for diagnosis of PJI. Clinical samples were tested by PCR with and without prior treatment with PMA and compared to conventional microbiological culture. The PCR assay included genus-specific primers for staphylococci and enterococci and species-specific primers for Cutibacterium acnes. The validated conditions of PMA treatment used in this study were $20 \mu \mathrm{M}$ concentration and 5 and $10 \mathrm{~min}$ of dark incubation and photo-activation respectively. 202 periprosthetic tissues and explanted prostheses from 60 episodes in 58 patients undergoing revision arthroplasties for either PJI or non-infective causes were tested, by culture, PCR, and PMA-PCR. 14 of the 60 episodes satisfied the Musculoskeletal Infection Society (MSIS) criteria for PJI and 46 did not. Sensitivity of culture, PCR, and PMA-PCR were $50 \%, 71 \%$, and $79 \%$ respectively. Specificities were $98 \%, 72 \%$, and $89 \%$ respectively. All figures were calculated for episodes rather than samples. PMA-PCR enhanced both the specificity and the sensitivity of PCR. It has the potential to detect residual bacterial viability prior to reimplantation in the two-stage revision for PJI.
\end{abstract}

Keywords Propidium monoazide $\cdot$ Polymerase chain reaction $\cdot$ Periprosthetic joint infection

\section{Introduction}

Prosthetic joint infection (PJI) is a devastating complication after joint replacement leading to great morbidity and significant burden to health care systems. It is one of the most feared modes of failure of arthroplasty because of the difficulty in diagnosis and treatment. Though the incidence of PJI according to Public Health England is currently $0.6 \%$ [1], infection accounted for $14.8 \%$ and $25.2 \%$ of revision operations after hip and knee arthroplasty respectively and was the

This study was presented in part as a poster at the ORS 2018, New Orleans, USA 10-13 March, 2017.

Roger Bayston

roger.bayston@ nottingham.ac.uk

1 Department of Academic Orthopaedics, Queen's Medical Centre, University of Nottingham, C Floor, West Block, Derby Road, Nottingham NG7 2UH, UK

2 Trauma and Orthopaedic Department, University of Nottingham Hospitals, Nottingham, UK most common cause of revision after knee replacements [2, 3]. The usual treatment for PJI is two-stage revision, where the infected joint is opened and explored, and all infected tissue and the prosthetic components are removed. At the second stage new prosthetic components are inserted but only after several weeks of antibiotic treatment to ensure as far as possible that the infecting bacteria have been eradicated. Tissue samples removed at the first stage are sent for culture, though this method has a low sensitivity. The prevalence of culture-negative PJI in the literature ranges from 7 [4] to more than $40 \%[5,6]$.

In the last decade, PCR has been evaluated in diagnosis of PJI in an attempt to overcome the limited sensitivity of culture methods [7-9]. While PCR is a rapid and relatively sensitive technique, it can falsely indicate the presence of residual infection at stage two revisions after antibiotic treatment due to dead bacteria. DNA from dead bacteria can persist for months in clinical samples after achievement of a clinical cure $[8,10]$, and PCR will overestimate the number of viable bacteria as the DNA from both live and dead bacteria will be amplified indiscriminately. 
Propidium monoazide (PMA) has been used to selectively limit the PCR to the viable bacteria [11-13], mainly in nonclinical settings. Propidium compounds have been known to bind to DNA and RNA for at least two decades. An added advantage is that intact bacterial cell membranes are impervious to propidium salts, allowing access only to the DNA of dead or damaged cells [14]. The presence of an azide group lets the molecule bind covalently to the DNA upon light exposure [15]. This cross-linking makes the DNA nonaccessible to the polymerase elongation because of structural changes and insolubility, leading to its loss during the DNA extraction process. The remaining unbound PMA is simultaneously deactivated upon light exposure and becomes no longer capable of binding to the DNA that will be released by extraction [16].

Therefore, inclusion of PMA in PCR assay for detection of residual infection in PJI, preventing DNA from non-viable bacteria from contributing to the PCR assay, might make the assay more reliable and increase its specificity.

In this study, PCR was performed with and without PMA pre-treatment, on clinical samples from PJI and aseptic revision arthroplasties in order to investigate this.

\section{Materials and methods}

\section{PMA optimisation}

PMA concentration, dark incubation, and photo-activation time periods were optimised. Each one of these parameters was tested separately while the other two variables were kept constant. As a first stage, these conditions were tested on laboratory-prepared live and dead bacterial suspensions. In a second stage, to mimic a clinical situation, the optimised conditions were tested using artificially spiked human tissue homogenates for validation. Organisms used in the optimisation were isolated from PJI cases in our laboratory.

Suspensions of Staphylococcus aureus, being the commonest PJI pathogen, were prepared with a concentration of $10^{5}$ colony-forming units ( $\left.\mathrm{cfu}\right) / \mathrm{mL}$ in phosphate buffered saline (PBS) and divided into halves. One half was killed by heating in a dry block at $95^{\circ} \mathrm{C}$ for $10 \mathrm{~min}$ while the other half was left viable. Bacterial killing was defined as a lack of growth after incubation on blood agar for $48 \mathrm{~h}$.

Each of the live and dead portions was further divided into two halves; one of each was treated with PMA (Biotium, Fremont, USA) and the other half left untreated. Dark incubation was done at $37{ }^{\circ} \mathrm{C}$ in a shaking incubator for adequate mixing. The PMA-Lite ${ }^{\mathrm{TM}}$ LED Photolysis Device (Biotium) was used for the photo-activation of the PMA.

GenuElute DNA extraction kit (Sigma-Aldrich, Missouri, USA) was used for bacterial DNA extraction following the manufacturer's protocol. PCR was run using Mx3005P
QPCR (Agilent, California, USA). Each sample was run in duplicate in the same PCR assay and each test was repeated three times. For each of the live and dead samples, difference in cycle threshold $\mathrm{Ct}(\Delta \mathrm{Ct})$ was calculated, where: $\Delta \mathrm{Ct}$ viable is the difference between the $\mathrm{Ct}$ value of viable bacteria with and without PMA treatment and $\Delta \mathrm{Ct}$ dead is the difference between the $\mathrm{Ct}$ value of dead bacteria with and without PMA treatment. The ideal PMA treatment conditions should have the highest $\Delta \mathrm{Ct}$ dead and lowest $\Delta \mathrm{Ct}$ viable.

For PMA concentration optimisation, four different PMA concentrations were tested: 10, 20, 50 and $100 \mu \mathrm{M}$. After addition of the PMA, samples were incubated in the dark for $5 \mathrm{~min}$ and then photo-activated for $20 \mathrm{~min}$.

For optimisation of dark incubation, a concentration of $20 \mu \mathrm{M}$ was used. 5,10 , and $30 \mathrm{~min}$ were tested with the same photo-activation time of $20 \mathrm{~min}$.

For photo-activation optimisation, a concentration of $20 \mu \mathrm{M}$ and a five-minute dark incubation were used. 10, 20, and $30 \mathrm{~min}$ were tested.

\section{Application of optimised PMA in clinical samples}

Using the optimum conditions above, clinical samples were examined. 202 periprosthetic tissues and/or explanted prosthesis samples were collected from 60 episodes in 58 patients undergoing revision arthroplasties due to either PJI or non-infective causes (eg aseptic loosening or periprosthetic fracture). The Musculoskeletal Infection Society (MSIS) definition of PJI was used [17]. Figure 1 is an overview of the processing of clinical samples.

Tissues were homogenized using the Roche magNA Lyser homogenizer (Hoffman-La Roche Ltd, Basel Switzerland) at a speed of $4500 \mathrm{rpm}$ for four cycles, each lasting $45 \mathrm{~s}$ [18]. Prostheses were sonicated in a precision sonicator set at $50 \mathrm{~Hz}$ (Ultrawave Ltd, Cardiff, UK) for $5 \mathrm{~min}$.

Homogenates and sonicates were used for aerobic and anaerobic cultures, PCR (PCR without PMA), and PMAPCR (viability PCR). For PMA treatment, $5 \mu \mathrm{L}$ of $2 \mathrm{mM}$ of the photo-reactive dye was added to the $500 \mathrm{~mL}$ sample in a dim-light room for a final concentration of $20 \mu \mathrm{M} / \mu \mathrm{L}$. The sample was then incubated in the dark for $5 \mathrm{~min}$ (covered with aluminium foil), while gently shaking the tubes to ensure proper mixing. PMA-Lite ${ }^{\mathrm{TM}}$ LED Photolysis Device was used for the photo-activation for $10 \mathrm{~min}$.

For DNA extraction, the GenuElute DNA extraction kit was used according to the manufacturer's instructions.

The PCR assay included genus-specific primers for staphylococci [19] and enterococci [20] and species-specific primers for Cutibacterium acnes [21]. The human glyceraldehyde-3-phosphate dehydrogenase (GAPDH) housekeeping gene [22] was amplified as an internal control of DNA extraction and possible PCR inhibition (Table 1). Separate PCR assays were used for each primer pair. 


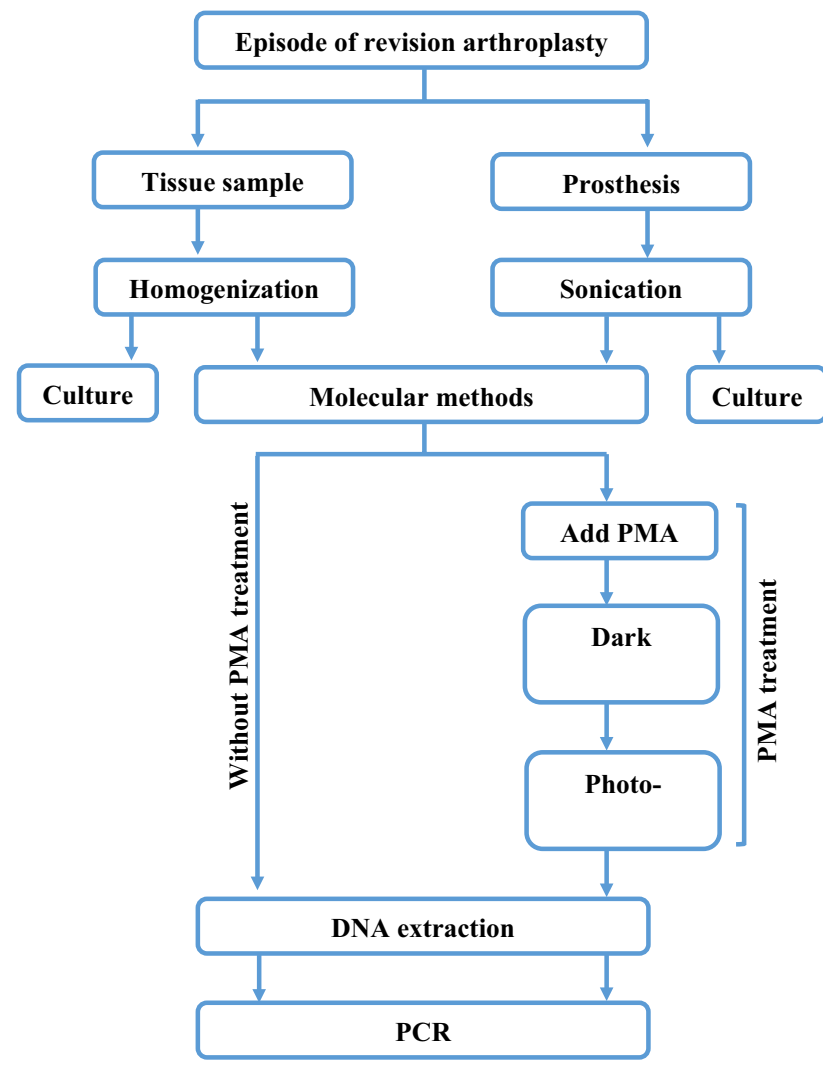

Fig. 1 Flowchart of processing of clinical samples

A final volume of $20 \mu \mathrm{L}$ was prepared in each tube by mixing $10 \mu \mathrm{L}$ of SensiFAST ${ }^{\text {M }}$ SYBR $^{\circledR}$ Lo-ROX Master Mix Kit (Bioline Reagents Ltd, London, UK), $0.5 \mu \mathrm{L}$ of each of the forward and reverse primer, $4 \mu \mathrm{L}$ nuclease free water and $5 \mu \mathrm{L}$ template or nuclease free water for non-template control (NTC) preparation. NTC samples were used both in PMA-treated and non-treated samples to confirm non contamination of the PMA. The terms viability PCR and conventional PCR are used in this manuscript to refer to PCR with and without PMA treatment respectively.

A positive tissue culture was defined as the isolation of the same organism from two or more tissue samples. A cutoff value of $10^{1} \mathrm{cfu} / \mathrm{mL}$ for the sonicate culture positivity was used as recommended by Trampuz et al. [23].
Collectively, a positive culture per episode was defined as either two or more positive tissue samples and/or positive sonicate culture.

A positive PCR sample was defined as any significant amplification (using the dissociation curve and/or gel electrophoresis) with a Ct value above the detection threshold. Definition of a positive PCR episode is an episode with two or more positive tissue samples and/or positive sonicate in the same assay.

\section{Effect of PMA on sensitivity of PCR assay in clinical samples}

Ten-fold serial dilution suspensions of fresh culture (18-24 h old) of E. faecalis were prepared from $10^{8}$ to $10^{1} \mathrm{cfu} / \mathrm{mL}$. Non-infected tissue homogenates were tested with PCR to ensure they were E. faecalis-free. $500 \mathrm{~mL}$ of each bacterial suspension concentration was added to the same amount of tissue homogenate and then divided; one half was treated with PMA and the other left untreated. DNA was then extracted and PCR run as described above. Samples were run in duplicate in each experiment and three independent experiments were carried out on three different days. In addition to a positive control and NTC, a clean tissue sample was tested to further ensure lack of contamination. $\mathrm{Ct}$ values of PMA treated samples were compared to their untreated equivalents.

\section{Statistical analysis}

Graphpad Prism 7 was used to analyse data and produce charts. Appropriate statistical tests were used according to the distribution of data. $p$ values $<0.05$ were considered significant. Using the above mentioned definitions, sensitivities, specificities, and accuracies of culture, PCR, PMA-PCR were calculated for the episodes rather than samples.

\section{Ethics}

Human tissue samples were collected under the ethics approval of the Nottingham Health Science Biobank.
Table 1 Sequences of primers used in the study

\begin{tabular}{llll}
\hline Bacteria & Gene & Primer sequence $\left(5^{\prime} \rightarrow 3^{\prime}\right)$ & References \\
\hline Staphylococci & tuf gene & $\begin{array}{l}\text { Forward: CAATGCCACAAACTCG } \\
\text { Reverse: GCTTCAGCGTAGTCTA }\end{array}$ & {$[19]$} \\
Enterococci & 23S rRNA & $\begin{array}{l}\text { Forward: AGAAATTCCAAACGAACTTG } \\
\text { Reverse: CAGTGCTCTACCTCCATCATT }\end{array}$ & {$[20]$} \\
C. acnes & Forward: GGGTTGTAAACCGCTTTCGCCT & {$[21]$} \\
& Geverse: GGCACACCCATCTCTGAGCAC & \\
& GAPDH & Forward: TCCCTGAGCTGAACGGGAAG & {$[22]$} \\
& & Reverse: CGCCTGCTTCACCACCTTCT & \\
\hline
\end{tabular}



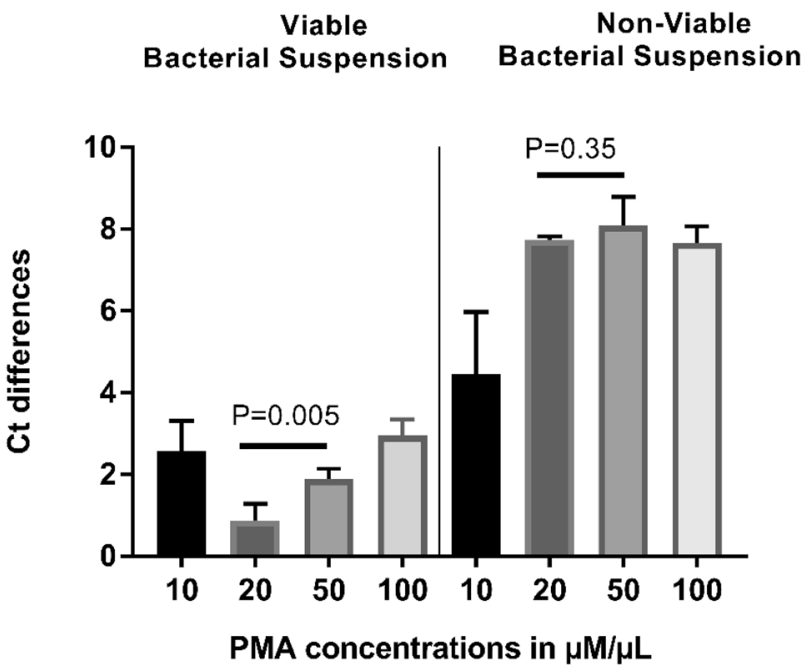

Fig. 2 Optimisation of PMA: effect of PMA concentration

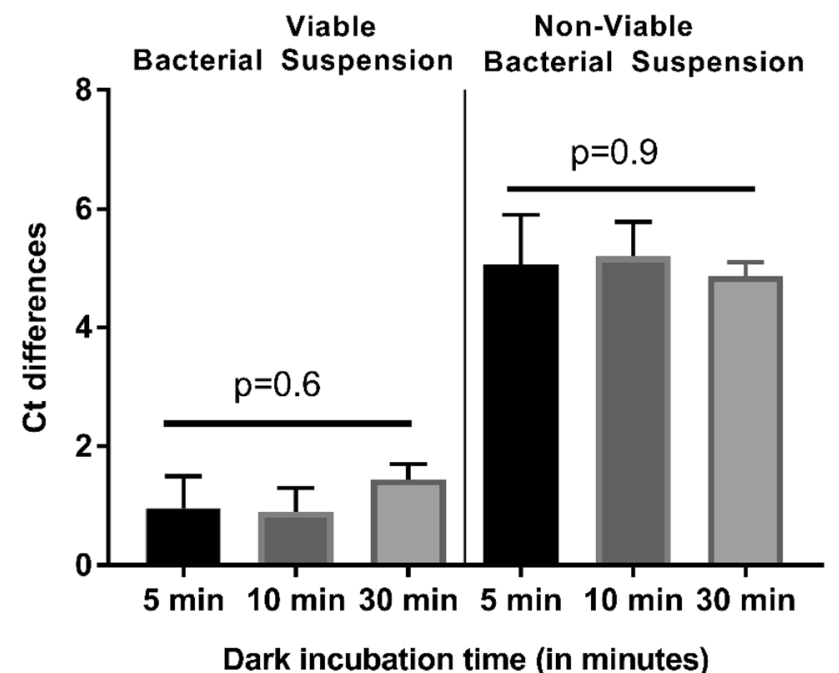

Fig. 3 Optimisation of PMA: effect of dark incubation time

\section{Results}

\section{PMA optimisation}

Figures 2, 3, 4, 5 and 6 show the results of PMA optimisation. $\Delta \mathrm{Ct}$ viable increased with the increase of PMA concentration from 20 to $100 \mu \mathrm{M}$. $\Delta \mathrm{Ct}$ dead increased with the increase in PMA concentration from 10 to $50 \mu \mathrm{M}$. The difference in $\Delta \mathrm{Ct}$ dead between 20 and $50 \mu \mathrm{M}$ concentration was statistically non-significant $(\mathrm{p}=0.35)$. However, $\Delta \mathrm{Ct}$ viable varied significantly between these two concentrations. $20 \mu \mathrm{M}$ was chosen to be used as it is the lowest concentration providing good live/dead discrimination (Fig. 1).

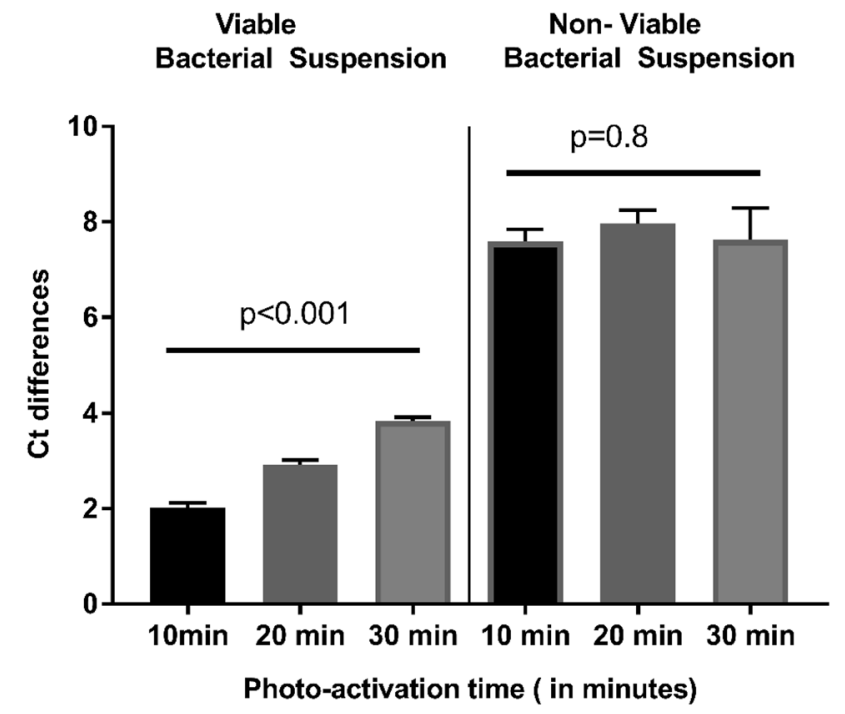

Fig. 4 Optimisation of PMA: effect of photo-activation time

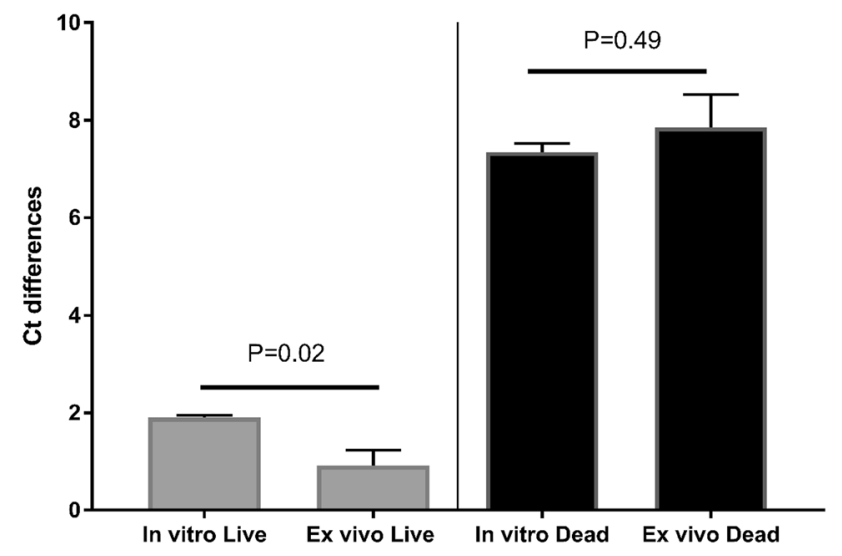

Fig. 5 Optimisation of PMA: comparison of in vitro and ex vivo $\Delta \mathrm{Ct}$ viable and $\Delta \mathrm{Ct}$ dead in bacterial suspensions

Differences in either $\Delta \mathrm{Ct}$ viable or $\Delta \mathrm{Ct}$ dead for different dark incubation times were not statistically significant (Fig. 2). The shortest tested time (5 min) was chosen for time-saving.

$\Delta \mathrm{Ct}$ viable, but not $\Delta \mathrm{Ct}$ dead, varied significantly between different photo-activation times (Fig. 3). As the ten-minute duration showed the lowest $\Delta \mathrm{Ct}$ viable, it was chosen to be the optimal photo-activation time.

\section{Application of optimised PMA in clinical samples}

Fourteen arthroplasty revision episodes satisfied the MSIS definition of PJI. Nine of them had pus-draining sinuses at the time of presentation. In addition forty-six episodes of aseptic failure were recruited into this study. Demographics of participants are shown in Table 2. 
Fig. 6 Optimisation of PMA: amplification plot of live and dead bacterial suspensions with/ without PMA treatment

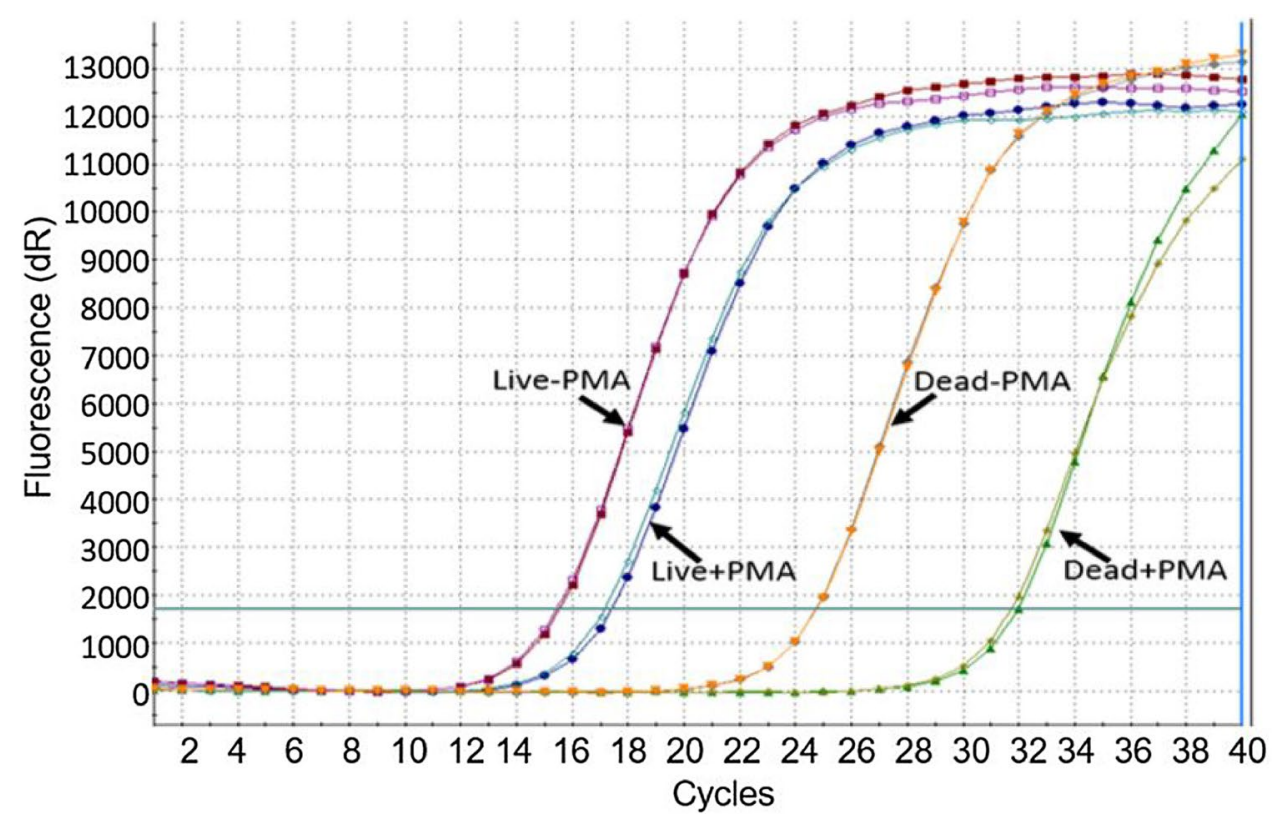

Table 2 Demographics of participants

\begin{tabular}{lll}
\hline & PJI & Aseptic failures \\
\hline Age in years & & \\
Median & 67.5 & 68 \\
Range & $51-83$ & $42-91$ \\
Gender: no. (\%) & & \\
Male & $7(50)$ & $19(41)$ \\
Female & $7(50)$ & $27(59)$ \\
Arthroplasty site: no. (\%) & & \\
Hip & $0(0)$ & $14(30.4)$ \\
Knee & $14(100)$ & $30(65.2)$ \\
Ankle & $0(0)$ & $2(4.4)$ \\
Time since primary replacement in months & \\
Median & 26 & 120 \\
Range & $1-168$ & $2-324$ \\
Number of revision: no. $(\%)$ & & $36(78)$ \\
First & $5(35.7)$ & $6(13)$ \\
Second & $5(35.7)$ & $4(9)$ \\
Third or more & $4(28.6)$ & \\
Presence of a sinus: no. (\%) & & $46(100)$ \\
Yes & $9(64.3)$ & $5(35.7)$ \\
No & & \\
\hline
\end{tabular}

${ }^{\text {a }}$ This data was unavailable in three episodes in the aseptic group

Sensitivity and specificity of culture methods was 50\% and 98\% respectively. Staphylococcus epidermidis and E. faecalis were isolated from three and two episodes respectively. S. aureus, S. lugdunensis were isolated from one episode each.
Of note, apart from the above mentioned 14 MSIS positive cases, there were two cases among the participants who were infected with streptococci (One with Streptococcus agalactiae and the other with Streptococcus mutans). These two cases were excluded from results analysis as these organisms are outside the panel of the PCR assays.

Among the 14 episodes of PJI included in the analysis, conventional PCR of periprosthetic tissues was positive in only two episodes while conventional PCR of sonicates was positive in nine episodes. Results of conventional and viability PCR are shown in Table 3.

In this study, the use of PMA converted the positive PCR results of eight aseptic episodes into negative, thus, increasing the specificity of PCR from 71.7 to $89.1 \%$. Interestingly, five out of these episodes had a suspicion of infection at some point of their clinical history (i.e. prolonged wound discharge or unexplained pain).

Ten samples (from eight episodes) tested positive with viability PCR and negative with conventional PCR. Seven and three out of these samples were in the enterococci and staphylococci assays respectively. Three of these episodes were revisions due to aseptic loosening. Other three episodes met the MSIS criteria and underwent first stage revision. One case was infected with positive intraoperative alpha-defensin testing but culture-negative. This case underwent debridement, antibiotics and implant retention (DAIR). The eighth episode was a re-implantation of presumably eradicated knee PJI case. This last case had polymicrobial infection and the sonicate tested positive for viability PCR of enterococci. 
Table 3 Results of conventional and viability PCR

\begin{tabular}{|c|c|c|c|c|}
\hline \multirow[t]{2}{*}{ Sample } & \multicolumn{2}{|l|}{ Conventional PCR } & \multicolumn{2}{|l|}{ Viability PCR } \\
\hline & $\%$ Sensitivity (95\% CI) & $\%$ Specificity $(95 \%$ CI) & \% Sensitivity (95\% CI) & $\%$ Specificity $(95 \% \mathrm{CI})$ \\
\hline Periprosthetic tissue & $15.38(1.92$ to 45.45$)$ & $100(92.13$ to 100$)$ & 23.08 (5.04 to 53.81$)$ & $100(92.13$ to 100$)$ \\
\hline Sonication fluid & $64.29(35.14$ to 87.24$)$ & $56.52(34.49$ to 76.81$)$ & $71.43(41.90$ to 91.61$)$ & 82.61 (61.22 to 95.05$)$ \\
\hline Either of them & $71.43(41.90$ to 91.61$)$ & $71.74(56.54$ to 84.01$)$ & $78.57(49.20$ to 95.34$)$ & $89.13(76.43$ to 96.38$)$ \\
\hline
\end{tabular}

\section{Effect of PMA on sensitivity of PCR assay in clinical samples}

Differences in Ct values between PMA-treated and untreated simulated infected human tissue samples for the concentrations between $10^{8}$ to $10^{2} \mathrm{cfu} / \mathrm{mL}$ were less than one cycle. However, the $10^{1} \mathrm{cfu} / \mathrm{mL}$ concentration was detected only in PMA-treated samples. The end reaction product was consistently higher for PMA-treated samples for the whole range of concentrations $(\mathrm{p}=0.01)$.

\section{Discussion}

In the absence of a "gold standard" test, laboratory diagnosis of PJI continues to be challenging. The use of PCR has been investigated in an attempt to improve the diagnosis, but still has very limited clinical application. This study reveals a potential to overcome the indiscriminate detection of bacterial DNA in PCR by pre-treatment of samples with PMA.

PMA has been widely used to restrict the PCR detection to live cells, mainly in a laboratory setting. However, clinical as well as environmental samples pose a complex nature that could negatively affect the PMA performance, such as turbidity of the sample $[12,24]$ and organic material contents [25]. As PMA has the ability to react not only with DNA from different sources but also with various inorganic and organic molecules [16], clinical samples can have a deleterious effect on PMA, hence the importance of PMA optimisation for these samples. In addition, the matrix of biofilms contains bacterial extracellular DNA, and this has been found to bind to propidium iodide [26].

As shown in the PMA optimisation data, upon applying the same PMA conditions used in bacterial suspensions to simulated infected human tissue samples (i.e. ex vivo), the live/dead discrimination was not compromised. On the contrary, $\Delta \mathrm{Ct}$ viable was significantly lower. On further scrutinizing these results, amplification of the live bacterial samples was noted to be delayed when spiked in tissues compared to bacterial suspension, which could be explained by probable PCR inhibition by tissue products. This delay in amplification was less in samples treated with PMA than untreated samples which raises a possibility that PMA could be inhibiting the action of some PCR inhibitors. Although the mechanism is unclear the ability of PMA to react with various inorganic and organic materials might be an explanation. In the case of dead bacteria (with much less bacterial DNA available for amplification), there was an even earlier amplification for samples treated with PMA, a finding that strongly argued for desirable impact of PMA on the sensitivity PCR assay.

Unexpectedly, the sensitivity of the viability PCR was found to be higher than the conventional PCR (78.57\% vs $71.43 \%$ ). Ten samples tested positive with viability PCR and negative with conventional PCR. PMA might increase the sensitivity of PCR and lower its detection limit. PMA does not bind selectively to prokaryotic DNA and can interact with DNA from any source such as damaged eukaryotic cells [16]. PMA could therefore interact with the abundant human DNA in clinical samples preventing or limiting the generation and accumulation of PCR inhibitors, explaining the observed increased sensitivity. To investigate this hypothesis, an experiment was designed to study the effect of PMA on PCR in simulated clinical samples in an attempt to explain these unexpected results. Interestingly, the $10^{1}$ $\mathrm{cfu} / \mathrm{mL}$ concentration was detected only by viability (PMA) PCR in our simulated infected clinical samples.

Our results of clinical samples showed that in periprosthetic tissues PCR has poor sensitivity (15.4\% for conventional PCR and $23 \%$ for viability PCR) as previously found by Ryu et al. [27], Suda et al. [28], and Huang et al. [29]. They reported sensitivities of $16 \%, 30.8 \%$, and $34 \%$ respectively. Several factors could contribute to the poor sensitivity of tissue PCR, including the small volume of samples used in PCR which makes it more liable to sampling errors. Difficult extraction of bacterial DNA because of the high viscosity of homogenates is another possible reason. Using larger volumes or higher concentrations may enhance the tissue PCR sensitivity. On the other hand, bacterial DNA in tissue samples would be overwhelmed with human genome DNA and loaded with PCR inhibitors. Potential abundance of PCR inhibitors in tissues also contributes significantly in this poor sensitivity. There is a need for techniques for purification of bacterial DNA and removal of human DNA for better results.

In this study, any amplification of the GAPDH gene was accepted as an indicator of lack of inhibition. We chose this external control (i.e. done in a separate aliquot) to 
avoid the potential interference of the target gene amplification by the co-amplification of the internal control [30].

With better understanding of the pathogenesis of PJI and biofilm development, retrieved prostheses have been appreciated as very valuable material for diagnosis. Sonication of prostheses has proved to be reliable, effective, and reproducible [23, 31]. Sonicates of implants have been used in both conventional and molecular microbiological methods, and more frequently than periprosthetic tissues as PCR material for PJI diagnosis, with superior sensitivity [27, 32, 33]. Our results agree with these studies as the sonicate PCR sensitivity was $64.3 \%$ and $71.4 \%$ for the conventional and viability PCR respectively compared to $15.4 \%$ and $23 \%$ for the periprosthetic tissues.

A major goal of this work was to determine the effect of prior PMA treatment of clinical samples on the performance of PCR in the diagnosis of PJI. Our results showed an increased specificity of PCR with PMA treatment.

Nocker et al. [15] has shown the usefulness of PMA in PCR studies in environmental situations, and Kobayashi [13] has shown its effect with PJI pathogens in vitro but recommended that it be validated with clinical samples. To the best of our knowledge, this is the first clinical study investigating the viability (PMA) PCR in the diagnosis of PJI. In this study, the use of PMA increased the specificity of PCR from 71.7 to $89.1 \%$ by converting the positive PCR results of eight aseptic episodes into negative. Interestingly, five out of these episodes had a suspicion of infection at some point of their clinical history (i.e. prolonged wound discharge or unexplained pain). In such cases, it is both challenging and crucial to decide how such a patient should be treated. Limiting the positive PCR results to viable bacteria could help to avoid unnecessary prolonged and costly treatment. On the other hand, persistence of the positive signal in PCR after PMA treatment, as in a further five aseptic episodes in our cohort, could identify these episodes as "at risk" and prompt closer and more frequent follow-up.

Our study has some limitations. Firstly, this is a single centre study with a relatively small number of participants. Small sample size resulted in wide confidence intervals of the calculated sensitivities and specificities. Secondly, the narrow PCR panel might have negatively affected the sensitivity. However, the primary focus of this research was to evaluate the effect of PMA on the performance of PCR in the diagnosis of PJI rather than testing the PCR per se. Furthermore, PMA optimisation was carried out for $S$. aureus only as it is one of the commonest causative pathogens of PJI. Different bacteria might require different optimised conditions. Other bacteria were not utilized in the optimisation process due to limited resources and they were found to work properly during the study. Multiple optimisations might deem necessary at a later stage.
In summary, pre-treatment of clinical samples with PMA has the potential to enhance both the specificity and sensitivity of PCR in the diagnosis of PJI. Further larger scale studies are needed prior to generalizing these finding and recommending the use of this technique in clinical settings.

Acknowledgements We thank the patients and the surgeons who participated in this study.

Funding This work was supported by Newton-Mosharafa Fund through the mission sector of the Egyptian ministry of higher education. MA was a PhD student in our institute supported by the funder. The funders had no role in study design, data collection and interpretation, or the decision to submit the work for publication.

\section{Compliance with ethical standards}

Conflict of interest All authors have no conflict of interest.

Open Access This article is distributed under the terms of the Creative Commons Attribution 4.0 International License (http://creativeco mmons.org/licenses/by/4.0/), which permits unrestricted use, distribution, and reproduction in any medium, provided you give appropriate credit to the original author(s) and the source, provide a link to the Creative Commons license, and indicate if changes were made.

\section{References}

1. Public Health England (2016) Surveillance of surgical site infections in NHS hospitals in England, 2015/16. Public Health England, London

2. Parvizi J, Pawasarat IM, Azzam KA, Joshi A, Hansen EN, Bozic KJ (2010) Periprosthetic joint infection: the economic impact of methicillin-resistant infections. J Arthroplasty 25(6 Suppl):103107. https://doi.org/10.1016/j.arth.2010.04.011

3. Bozic KJ, Kurtz SM, Lau E, Ong K, Chiu V, Vail TP, Rubash HE, Berry DJ (2010) The epidemiology of revision total knee arthroplasty in the United States. Clin Orthop Relat Res 468(1):45-51. https://doi.org/10.1007/s11999-009-0945-0

4. Berbari EF, Marculescu C, Sia I, Lahr BD, Hanssen AD, Steckelberg JM, Gullerud R, Osmon DR (2007) Culture-negative prosthetic joint infection. Clin Infect Dis 45(9):1113-1119. https://doi. org/10.1086/522184

5. Kim YH, Kulkarni SS, Park JW, Kim JS, Oh HK, Rastogi D (2015) Comparison of infection control rates and clinical outcomes in culture-positive and culture-negative infected totalknee arthroplasty. J Orthop 12(Suppl 1):S37-43. https://doi. org/10.1016/j.jor.2015.01.020

6. Bejon P, Berendt A, Atkins BL, Green N, Parry H, Masters S, McLardy-Smith P, Gundle R, Byren I (2010) Two-stage revision for prosthetic joint infection: predictors of outcome and the role of reimplantation microbiology. J Antimicrob Chemother 65(3):569575. https://doi.org/10.1093/jac/dkp469

7. Achermann Y, Vogt M, Leunig M, Wust J, Trampuz A (2010) Improved diagnosis of periprosthetic joint infection by multiplex PCR of sonication fluid from removed implants. J Clin Microbiol 48(4):1208-1214. https://doi.org/10.1128/jcm.00006-10

8. Bemer P, Plouzeau C, Tande D, Leger J, Giraudeau B, Valentin AS, Jolivet-Gougeon A, Vincent P, Corvec S, Gibaud S, Juvin ME, Hery-Arnaud G, Lemarie C, Kempf M, Bret L, Quentin R, 
Coffre C, de Pinieux G, Bernard L, Burucoa C (2014) Evaluation of $16 \mathrm{~S}$ rRNA gene PCR sensitivity and specificity for diagnosis of prosthetic joint infection: a prospective multicenter crosssectional study. J Clin Microbiol 52(10):3583-3589. https://doi. org $/ 10.1128 / \mathrm{jcm} .01459-14$

9. Bereza P, Ekiel A, Augusciak-Duma A, Aptekorz M, Wilk I, Kusz D, Wojciechowski P, Sieron AL, Martirosian G (2016) Comparison of cultures and 16S rRNA sequencing for identification of bacteria in two-stage revision arthroplasties: preliminary report. BMC Musculoskelet Disord 17:138. https://doi.org/10.1186/ s12891-016-0991-1

10. Branger S, Casalta JP, Habib G, Collard F, Raoult D (2003) Streptococcus pneumoniae endocarditis: persistence of DNA on heart valve material 7 years after infectious episode. J Clin Microbiol 41(9):4435-4437

11. Nikolayevskyy V, Miotto P, Pimkina E, Balabanova Y, Kontsevaya I, Ignatyeva O, Ambrosi A, Skenders G, Ambrozaitis A, Kovalyov A, Sadykhova A, Simak T, Kritsky A, Mironova S, Tikhonova O, Dubrovskaya Y, Rodionova Y, Cirillo D, Drobniewski F (2015) Utility of propidium monoazide viability assay as a biomarker for a tuberculosis disease. Tuberculosis (Edinburgh, Scotland) 95(2):179-185. https://doi.org/10.1016/j.tube.2014.11.005

12. Bae S, Wuertz S (2009) Discrimination of viable and dead fecal Bacteroidales bacteria by quantitative PCR with propidium monoazide. Appl Environ Microbiol 75(9):2940-2944. https://doi. org/10.1128/aem.01333-08

13. Kobayashi H, Oethinger M, Tuohy MJ, Hall GS, Bauer TW (2009) Improving clinical significance of PCR: use of propidium monoazide to distinguish viable from dead Staphylococcus aureus and Staphylococcus epidermidis. J Orthop Res 27(9):1243-1247. https ://doi.org/10.1002/jor.20872

14. Chang B, Taguri T, Sugiyama K, Amemura-Maekawa J, Kura F, Watanabe H (2010) Comparison of ethidium monoazide and propidium monoazide for the selective detection of viable Legionella cells. Jpn J Infect Dis 63(2):119-123

15. Nocker A, Cheung CY, Camper AK (2006) Comparison of propidium monoazide with ethidium monoazide for differentiation of live vs. dead bacteria by selective removal of DNA from dead cells. J Microbiol Methods 67(2):310-320. https://doi. org/10.1016/j.mimet.2006.04.015

16. Taylor MJ, Bentham RH, Ross KE (2014) Limitations of using propidium monoazide with qPCR to discriminate between live and dead Legionella in biofilm samples. Microbiol Insights 7:15-24. https://doi.org/10.4137/mbi.s17723

17. Parvizi J, Zmistowski B, Berbari EF, Bauer TW, Springer BD, Della Valle CJ, Garvin KL, Mont MA, Wongworawat MD, Zalavras CG (2011) New definition for periprosthetic joint infection: from the Workgroup of the Musculoskeletal Infection Society. Clin Orthop Relat Res 469(11):2992-2994. https://doi. org/10.1007/s11999-011-2102-9

18. Askar M, Ashraf W, Scammell B, Bayston R (2019) Comparison of different human tissue processing methods for maximization of bacterial recovery. Eur J Clin Microbiol Infect Dis 38(1):149-155. https://doi.org/10.1007/s10096-018-3406-4

19. Sakai H, Procop GW, Kobayashi N, Togawa D, Wilson DA, Borden L, Krebs V, Bauer TW (2004) Simultaneous detection of Staphylococcus aureus and coagulase-negative staphylococci in positive blood cultures by real-time PCR with two fluorescence resonance energy transfer probe sets. J Clin Microbiol 42(12):5739-5744. https://doi.org/10.1128/jcm.42.12.5739-5744.2004

20. Ryu H, Henson M, Elk M, Toledo-Hernandez C, Griffith J, Blackwood D, Noble R, Gourmelon M, Glassmeyer S, Santo Domingo JW (2013) Development of quantitative PCR assays targeting the 16S rRNA. Appl Environ Microbiol 79(1):196-204. https://doi. org/10.1128/aem.02802-12

21. Sfanos KS, Isaacs WB (2008) An evaluation of PCR primer sets used for detection of Propionibacterium acnes in prostate tissue samples. Prostate 68(14):1492-1495. https://doi.org/10.1002/ pros. 20820

22. Rak M, Barlic-Maganja D, Kavcic M, Trebse R, Cor A (2015) Identification of the same species in at least two intra-operative samples for prosthetic joint infection diagnostics yields the best results with broad-range polymerase chain reaction. Int Orthop 39(5):975-979. https://doi.org/10.1007/s00264-014-2552-2

23. Trampuz A, Piper KE, Jacobson MJ, Hanssen AD, Unni KK, Osmon DR, Mandrekar JN, Cockerill FR, Steckelberg JM, Greenleaf JF, Patel R (2007) Sonication of removed hip and knee prostheses for diagnosis of infection. N Engl J Med 357(7):654-663. https://doi.org/10.1056/NEJMoa061588

24. Varma M, Field R, Stinson M, Rukovets B, Wymer L, Haugland R (2009) Quantitative real-time PCR analysis of total and propidium monoazide-resistant fecal indicator bacteria in wastewater. Water Res 43(19):4790-4801. https://doi.org/10.1016/j.watre s.2009.05.031

25. Fittipaldi M, Codony F, Adrados B, Camper AK, Morato J (2011) Viable real-time PCR in environmental samples: can all data be interpreted directly? Microb Ecol 61(1):7-12. https://doi. org/10.1007/s00248-010-9719-1

26. Rosenberg M, Azevedo NF, Ivask A (2019) Propidium iodide staining underestimates viability of adherent bacterial cells. Sci Rep 9(1):6483. https://doi.org/10.1038/s41598-019-42906-3

27. Ryu SY, Greenwood-Quaintance KE, Hanssen AD, Mandrekar JN, Patel R (2014) Low sensitivity of periprosthetic tissue PCR for prosthetic knee infection diagnosis. Diagn Microbiol Infect Dis 79(4):448-453. https://doi.org/10.1016/j.diagmicrob io.2014.03.021

28. Suda AJ, Tinelli M, Beisemann ND, Weil Y, Khoury A, Bischel OE (2017) Diagnosis of periprosthetic joint infection using alpha-defensin test or multiplex-PCR: ideal diagnostic test still not found. Int Orthop 41(7):1307-1313. https://doi.org/10.1007/ s00264-017-3412-7

29. Huang Z, Wu Q, Fang X, Li W, Zhang C, Zeng H, Wang Q, Lin J, Zhang W (2018) Comparison of culture and broad-range polymerase chain reaction methods for diagnosing periprosthetic joint infection: analysis of joint fluid, periprosthetic tissue, and sonicated fluid. Int Orthop. https://doi.org/10.1007/s0026 4-018-3827-9

30. Hofmann MA (2003) Construction of an infectious chimeric classical swine fever virus containing the $5^{\prime} \mathrm{UTR}$ of bovine viral diarrhea virus, and its application as a universal internal positive control in real-time RT-PCR. J Virol Methods 114(1):77-90

31. Portillo ME, Salvado M, Trampuz A, Plasencia V, Rodriguez-Villasante M, Sorli L, Puig L, Horcajada JP (2013) Sonication versus vortexing of implants for diagnosis of prosthetic joint infection. J Clin Microbiol 51(2):591-594. https://doi.org/10.1128/jcm.02482 $-12$

32. Bjerkan G, Witso E, Nor A, Viset T, Loseth K, Lydersen S, Persen L, Bergh K (2012) A comprehensive microbiological evaluation of fifty-four patients undergoing revision surgery due to prosthetic joint loosening. J Med Microbiol 61(Pt 4):572-581. https://doi. org/10.1099/jmm.0.036087-0

33. Rak M, KavcIc M, Trebse R, Co RA (2016) Detection of bacteria with molecular methods in prosthetic joint infection: sonication fluid better than periprosthetic tissue. Acta Orthop 87(4):339-345. https://doi.org/10.3109/17453674.2016.1165558

Publisher's Note Springer Nature remains neutral with regard to jurisdictional claims in published maps and institutional affiliations. 